sumably the lower most border of VL nucleus.

It is concluded from the systematic study of VL stimulation on motor system, that VL is primarily responsible for the muscle tone regulation and tremor is increased or decreased in amplitude secondarily as a result of the muscle tone increase.

There were also found an area at the deeper structure of which high frequency stimulation increased the tremor amplitude or suppressed it abruptly and completely without detectable change of muscle tone.

\title{
54. Spatial Interrelationship of Intracerebral Reference Points and Basal Ganglia
}

\author{
Akio Suzuki \\ Dept. of Neurological Surgery, Okayama University Medical School
}

Spatial interrelationship of various intracerebral reference points and basal ganglia were investigated in 15 brains of Japanese cadavers, and three-dimensional atlas of those basal ganglia was made by graphic method. Furthermore, the values of variations of their location were calculated.

1) Average composite zones of basal ganglia in relatio to the midpoint of $\mathrm{Ca}-\mathrm{Cp}$ line are shown in the following table.

\begin{tabular}{llcllll}
\hline & $\begin{array}{l}\text { medial } \\
\text { border }\end{array}$ & $\begin{array}{l}\text { lateral } \\
\text { border }\end{array}$ & $\begin{array}{l}\text { superior } \\
\text { border }\end{array}$ & $\begin{array}{l}\text { inferior } \\
\text { border }\end{array}$ & $\begin{array}{l}\text { anterior } \\
\text { border }\end{array}$ & $\begin{array}{l}\text { posterior } \\
\text { border }\end{array}$ \\
\hline corpus Luysi & $5.9 \mathrm{~mm}$ & $13.9 \mathrm{~mm}$ & $-1.1 \mathrm{~mm}$ & $-8.7 \mathrm{~mm}$ & $+0.9 \mathrm{~mm}$ & $-7.8 \mathrm{~mm}$ \\
$\begin{array}{l}\text { nucleus ruber } \\
\text { substantia nigra }\end{array}$ & 1.0 & 7.5 & -4.0 & -12.1 & -2.8 & -11.1 \\
$\begin{array}{c}\text { nucleus dorso- } \\
\text { medialis thalami }\end{array}$ & 0.8 & 13.4 & -5.1 & -17.5 & +2.3 & -14.6 \\
$\begin{array}{c}\text { nucleus centrum } \\
\text { medianum thalami }\end{array}$ & 3.9 & 11.9 & +7.6 & -0.6 & -2.2 & -12.1 \\
$\begin{array}{c}\text { iateral and ventral } \\
\text { group of the }\end{array}$ & 4.5 & 18.5 & +18.5 & -1.7 & +5.5 & -12.4 \\
$\quad$ thalamus & 8.5 & +13.2 & +1.4 & +3.2 & -13.4 \\
globus pallidus & 8.5 & 24.9 & +10.2 & -5.3 & +16.8 & -7.4 \\
putamen & 11.6 & 30.3 & +18.5 & -7.4 & +28.8 & -11.5 \\
\hline
\end{tabular}

$(+)$ : superior or anterior to reference point

$(\rightarrow)$ : inferior or posterior to reference point

2) The value of positional variations of the basal ganglia may become changed as the reference point is changed. Therefore, by selecting the reference point closer to the target point, anatomical deviation can be minimized so that the stereotaxic procedure may be more accurate and correct.

$$
-83-
$$

